\title{
Review \\ Update on Stachybotrys chartarum-Black Mold Perceived as Toxigenic and Potentially Pathogenic to Humans
}

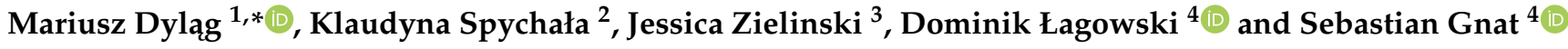 \\ 1 Department of Mycology and Genetics, Faculty of Biological Sciences, University of Wroclaw, \\ 51-148 Wroclaw, Poland \\ 2 Student Scientific Circle (SKN Mykobiota), Faculty of Biological Sciences, University of Wroclaw, \\ 51-148 Wroclaw, Poland; 299130@uwr.edu.pl \\ 3 Department of Oral Health Sciences, Medical University of South Carolina, Charleston, SC 29425, USA; \\ zielinsk@musc.edu \\ 4 Department of Veterinary Microbiology, Faculty of Veterinary Medicine, University of Life Sciences in Lublin, \\ 20-950 Lublin, Poland; dominik.lagowski@up.lublin.pl (D.Ł.); sebastian.gnat@up.lublin.pl (S.G.) \\ * Correspondence: mariusz.dylag@uwr.edu.pl
}

check for updates

Citation: Dyląg, M.; Spychała, K.; Zielinski, J.; Łagowski, D.; Gnat, S. Update on Stachybotrys chartarum-Black Mold Perceived as Toxigenic and Potentially Pathogenic to Humans. Biology 2022, 11, 352. https://doi.org/10.3390/biology 11030352

Received: 19 January 2022

Accepted: 22 February 2022

Published: 23 February 2022

Publisher's Note: MDPI stays neutral with regard to jurisdictional claims in published maps and institutional affiliations.

Copyright: (C) 2022 by the authors. Licensee MDPI, Basel, Switzerland. This article is an open access article distributed under the terms and conditions of the Creative Commons Attribution (CC BY) license (https:// creativecommons.org/licenses/by/ $4.0 /$ )
Simple Summary: Among the 123 currently accepted species of the genus Stachybotrys, S. chartarum consistently deserves special attention. This one is the most frequently isolated species of the aforementioned genus and one of the world's 10 most hazardous fungi. S. chartarum owes its notoriety to the secondary metabolites that are released in the host environment. Interaction of these metabolites with mucous membranes of the respiratory or digestive tract and with the skin can induce necrotic changes and even life-threatening pulmonary or gastrointestinal hemorrhage. Pulmonary hemorrhage was of major concern to the public when, in the period of 1993-1998, this ailment was identified in 138 infants in Cleveland, Ohio, USA, among which 12 cases were fatal. Since this first documented outbreak, the number of publications dealing with the toxigenic properties of this fungus, and even its potential pathogenicity, has rapidly grown. In this comprehensive review we present the most updated information about taxonomy, macro- and micromorphology, biology and ecology of this fungus. Within this work, we focus on the factors that prompted this fungus to be extremely dangerous for people and animals living in moldy conditions, as well as antifungals efficient in its eradication from indoor environments.

Abstract: In nature, there are many species of fungi known to produce various mycotoxins, allergens and volatile organic compounds (VOCs), as well as the commonly known etiological agents of various types of mycoses. So far, none of them have provoked so much emotion among homeowners, builders, conservators, mycologists and clinicians as Stachybotrys chartarum. This species compared to fungi of the genera Fusarium and Aspergillus is not as frequently described to be a micromycete that is toxigenic and hazardous to human and animal health, but interest in it has been growing consistently for three decades. Depending on the authors of any given review article, attention is focused either on the clinical aspects alongside the role of this fungus in deterioration of biomaterials, or aspects related to its biology, ecology and taxonomic position. On the one hand, it is well established that inhalation of conidia, containing the highest concentrations of toxic metabolites, may cause serious damage to the mammalian lung, particularly with repeated exposure. On the other hand, we can find articles in which authors demonstrate that $S$. chartarum conidia can germinate and form hyphae in lungs but are not able to establish an effective infection. Finally, we can find case reports that suggest that $S$. chartarum infection is linked with acute pulmonary hemorrhage, based on fungal structures recovered from patient lung tissue. New scientific reports have verified the current state of knowledge and note that clinical significance of this fungus is exceedingly controversial. For these reasons, understanding $S$. chartarum requires reviewing the well-known toxigenic features and harmful factors associated with this fungus, by gathering the newest ones into a coherent whole. The research problem related to this fungus seems to be not overly publicized, and there is still a demand to truthfully define the real threats of $S$. chartarum and phylogenetically related species. The most important problem, which should be fully elucidated as soon as possible, remains the clarification of 
the pathogenicity of $S$. chartarum and related species. Maybe it is urgent time to ask a critical question, namely what exactly do we know 28 years after the outbreak of pulmonary hemorrhage in infants in Cleveland, Ohio, USA most likely caused by S. chartarum?

Keywords: black toxic mold; biology; ecology; pathogenicity; mycotoxins; clinical implications

\section{Introduction}

People spend approximately $90 \%$ of their life indoors inhaling about $15 \mathrm{~m}^{3}$ of ambient air daily [1,2]. Paradoxically, the exposure to indoor air pollution might be stronger than exposure to the impurities of the outdoor air [1,3,4]. Fungal propagules can enter the living space of a building from the outside air through opened windows or doors [5]. It is commonly known that many respiratory symptoms are associated with staying in homes that have humidity problems and the presence of molds on various building materials [3,6]. Poor indoor air quality can cause different occupational diseases, many of which can be associated with toxigenic fungi $[7,8]$. Since 1993, when Stachybotrys chartarum was discovered as an etiological agent directly related with acute pulmonary hemorrhage in infants from Cleveland, Ohio, USA $[9,10]$, the interest in this black fungus systematically grew. S. chartarum is not only a damp building-related fungus found under special conditions, this micromycete fungus is much more common than it might be assumed, and is favored by relatively high humidity and cellulose-rich materials [11]. Taking this into account, it seems justified to explore the topics related to this fungus in order to consciously and properly protect houses and public utility rooms against its occurrence. After many changes, the current taxonomic position of this black fungus was established [12,13], which was certainly due to new data based on the whole-genome sequencing of $S$. chartarum and S. chlorohalonata strains [14]. Similarly, some inconsistencies in the descriptions of the micromorphology of this fungus were resolved, such as the fact that all the strains of Stachybotrys genus produce single-celled conidia [15]. Moreover, actualized data on the range of $\mathrm{pH}$, temperature and water activity factor $\left(\mathrm{a}_{\mathrm{w}}\right)$ allow us to precisely define the conditions under which growth of this fungus may occur [16-18], which in turn are crucial to prevent biodeterioration processes. Actually, it is commonly known that $S$. chartarum as a tertiary colonizer requires $\mathrm{a}_{\mathrm{w}}>0.9$ and relative humidity $(\mathrm{RH})>90 \%$ to grow $[19,20]$. People can be exposed to this fungus via dermal contact, ingestion and inhalation. S. chartarum is capable of producing mycotoxins, which can be divided into three structural groups, macrocyclic trichothecenes (MCTs, e.g., satratoxins), atranones and immunosuppressive phenylspirodrimanes (PSDs) [21,22]. Among the most recently isolated, three new dolabellane-type diterpenoids and three new atranones showed interesting antimicrobial properties [23]. It is commonly known that most of the mycotoxins related with this species are very harmful for humans. It should be noted, however, that the Centers for Disease Control and Prevention (CDC), due to the lack of complete documentation of pulmonary hemorrhage cases described in the years 1993-1996, does not allow for the conclusion that $S$. chartarum unequivocally was the etiological agent for this ailment in infants [24]. However, it is impossible not to notice that $91 \%$ of the 52 cases of infant pulmonary hemorrhage described so far have been associated with the presence of $S$. chartarum in the homes of the studied patients $[13,25]$. Due to the fact that $S$. chartarum is one of the world's 10 most feared fungi [26], and the problematic issues raised in this paper have not yet been explained, it seems justified to pay attention to this black mold.

\section{Taxonomic Position}

Stachybotrys chartarum (Ehrenb.) S. Hughes (1958) [12,13,27] was isolated for the first time by Corda in 1837 from wallpaper in a house in Prague (Czech Republic) and then described as Stachybotrys atra $[12,13,28]$. Current taxonomic position and known synonyms of this fungus are given in Table 1. 
This species belongs to the genus Stachybotrys, family Stachybotryaceae, order Hypocreales, subclass Hypocreomycetidae, class Sordariomycetes, subphylum Pezizomycotina, phylum Ascomycota, subkingdom Dikarya and kingdom Fungi [30]. S. chartarum is also known by 132 synonyms (Table 1 ). Currently, the name S. chartarum is commonly accepted and used by mycologists worldwide [12,13,15]. According to Corda's description from 1837, the conidia of this species were to be two chambered. This finding was controversial and finally resolved by Bisby $[12,13,15,31]$. It is now commonly known that all strains of Stachybotrys genus produce single-celled conidia [15,32]. The species Stachybotrys junnanensis described by Kong [33], Stachybotrys chlorohalonata described by Andersen et al. [34,35] and also Stachybotrys eucylindrospora described by Wiederhold et al. [36] are very similar to $S$. chartarum and quite difficult to distinguish. Moreover, the variation in the size and shape of phialides and conidia makes it difficult to identify S. chartarum. Due to the fact that color and ornamentation of conidia change with age [15,37], it is easy to misidentify S. chartarum for such species as S. chlorohalonata, S. yunnanensis, Stachybotrys albipes and Stachybotrys elegans. For this reason, molecular biology techniques are an alternative solution enabling unambiguous identification of species of Stachybotrys taxa [38-43], especially those recently established based on fast and reliable MALDI-TOF MS identification method [44,45]. Sometimes, however, even well-designed specific primers used in real-time PCR procedure do not differentiate S. chartarum from S. chlorohalonata or S. yunnanensis [15]. It is believed that the concept of the species $S$. chartarum is still broad [15]. Since the whole genomes of three S. chartarum, one S. chlorohalonata and a few other Stachybotrys spp. strains have been sequenced, it has been possible to show differences in the context of secondary metabolites produced at the genotype level [46]. Comprehensive analyses of genomes of three $S$. chartarum and one $S$. chlorohalonata strains revealed two mutually exclusive toxin chemotypes, one producing satratoxins (strains IBT 40293 and IBT 7711), and the second one synthesizing atranones (strains IBT 40285 and IBT 40288). The recent studies clearly explain why a strain combining the simultaneous ability to synthesize satratoxins and atranones has never been observed [14]. Apart from the differentiation at the level of strain metabolomes, the genus Stachybotrys currently includes 12 species and is characterized by conidiophores branching at the basal septum and the presence of thick-walled phialoconidia that are usually sticky and ornamentated [12]. Currently, it is also well known that Memnoniella is a synonym of Stachybotrys [13]. Phylogenetic studies by Castlebury et al. [47] and Summerbell et al. [48] allow for the distinction of three genera, Myrothecium, Peethambara and Stachybotrys, which constitute a monophyletic lineage distinct from the other families within the Hypocreales. Later, extensive studies based on multi-locus molecular phylogenetic analyses revealed that the genera Myrothecium and Stachybotrys are polyphyletic. Furthermore, this led to the introduction of 13 new genera with myrothecium-like morphology and 8 new genera with stachybotrys-like morphology [12]. The family of Stachybotryaceae also includes other anamorphic genera that, like S. chartarum, are capable of synthesizing DHN melanin or producing mycotoxins that are dangerous to mammals, such as the genera Alfaria and Myrothecium [12]. The existence of the sexual state of $S$. chartarum was already postulated by Castellani [47], but for the first time it was fully described based on molecular phylogeny techniques, which revealed that Ornatispora and Melanopsamma are its teleomorphs [13] and both formed eight-spored asci inside perithecia [12]. These sexual genera are also synonyms of Stachybotrys [13]. The vast majority of teleomorphs known to be representatives of this family create perithecial ascomata that are either semi or totally immersed in host tissue. There are characterized by natural resistance to $10 \% \mathrm{KOH}$ in the presence of which the mycelium structures do not discolor [12]. Both the asexual and the sexual stages of Myrothecium are very similar to those known for representatives of the genus Stachybotrys (Melanopsamma) [47,49]. Furthermore, species of the genus Myrothecium, in particular M. roridum and M. verrucaria, like Stachybotrys chartarum, produce secondary metabolites that are highly toxic to cells of other eukaryotes [50-52]. 
Table 1. Current taxonomic position of Stachybotrys chartarum (Ehrenb.) S. Hughes (1958) and related species $^{1-4}$

\begin{tabular}{lll}
\hline Taxon Name & Current Name & Synonyms \\
\hline Kingdom & Fungi \\
\hline Subkingdom & Dikarya \\
\hline Phylum & Ascomycota \\
\hline Subphylum & Pezizomycotina \\
\hline Class & Sordariomycetes \\
\hline Subclass & Hypocreomycetidae & \\
\hline Order & Hypocreales & Fuckelina; Gliobotrys; Hyalobotrys; Hyalostachybotrys; \\
\hline Family & Stachybotryaceae & Memnoniella; Spinomyces; Synsporium \\
\hline Genus & Stachybotrys &
\end{tabular}

Currently accepted species ${ }^{1-4}$

S. aksuensis; S. albipes;

S. aloicola; S. alternans;

S. alternans var. alterans; $S$. alternans var. atoxicus;

S. asperulus; S. atra f. genuina;

S. atra var. atra; S. atrogriseus;

S. atrus; S. atrus f. atrus;

S. atrus f. lobatus; S. atrus var. atrus;

S. atrus var. brevicaulis; S. atrus var. cylindrosporus;

S. atrus var. microsporus; S. aurantius;

S. bambusicola; S. biformis;

S. bisbyi; S. breviusculus;

S. cannae; S. chartarum;

S. chlorohalonata; S. clitoriae;

S. cordylines; S. crassus;

S. cylindrosporus; S. dakotensis;

S. dichrous; S. dolichophialis;

S. echinatus; S. elasticae;

S. elastus; S. elegans;

S. elongatus; S. eucylindrospora

S. freycinetiae; S. frondicola;

S. gamsii; S. globosus;

S. gracilis; S. guttulisporus,

S. havanensis; S. humilis;

S. indicoides; S. indicus;

S. jiangziensis; S. kampalensis;

S. kapiti; S. klebahnii;

S. leprosus; S. levisporus;

S. limonisporus; S. littoralis;

S. lobulatus; S. lobulatus var. lobulatus;

S. longisporus; S. longistipitatus;

S. lunzinensis; S. magniferae;

S. mexicanus; S. microsporus;

S. mohanramii; S. musae;

S. nepalensis; S. nephrodes;

S. nephrospora; S. nielamuensis;

S. nilagirica; S. oenanthes;

S. oleronensis; S. pallescens

S. palmae; S. palmicola;

S. palmijunci; S. papyrogena;

S. parva; S. parvispora;

S. phaeophialis; S. proliferata;

S. pulchra; S. punctatus;

S. queenslandica; S. ramosa;

S. reniformis; S. renispora;

S. renisporoides; $S$. reniverrucosa;

S. ruwenzoriensis; S. saccharii;

S. sansevieriae; S. sansevieriicola;

S. scabra; S. setosa;

S. sinuatophora; S. socia;

S. sphaerospora; S. stilboidea;

S. subcylindrosporus; S. subreniformis

S. subsimplex; S. subsylvaticus;

S. suthepensis; S. taiwanensis;

S. terrestris; S. thaxteri;

S. theobromae; S. thermotolerans;

S. variabilis; S. verrucispora;

S. verrucosa; S. virgata;

S. voglinii; S. waitakere;

S. xigazenensis; S. yunnanensis

S. yushuensis; S. zeae:

S. zhangmuensis; S. zingiberis; S. zuckii

${ }^{1}$ based on Species Fungorum website [30]. ${ }^{2}$ according to Lombard et al., Persoonia 2016, 36, 156-246 [12]. ${ }^{3}$ based on MycoBank website [29]. ${ }^{4}$ according to Wang et al., Fungal Diversity (2015) 71, 17-83 [13]. 


\section{Species Description}

S. chartarum is usually overgrown by other micromycete fungi, especially of the genera Aspergillus and Penicillium, so it was often impossible to isolate it from building materials in flooded houses, even if those were very infested with this fungus. To obtain a pure culture of strain, it is best to use media rich in cellulose and low in sugar and nitrogen to compete with other molds typical for indoor air, especially from the genera Penicillium and Aspergillus. Media containing cellulose as the sole source of carbon are also recommended [10]. Malt extract agar (MEA) and potato dextrose agar (PDA) media (Figure 1A-C) are used commonly in studies on the characterization of Stachybotrys spp. $[21,35,53]$. S. chartarum on MEA initially forms gray-white and later gray-black colonies on the surface of which bands of dark gray hyphae form. While the reverse side of the colony remains black all the time, secondary mycelium, most often white in color, may develop on the obverse [54]. Mentioned ability to form dark pigmented structures of mycelium, specifically rich in 1,8-dihydroxynaphthalene (DHN) melanin, is typical for members of the Stachybotrys genus with the exception of Stachybotrys bisby, which forms hyaline mycelia and conidia and can be found on Oryza sativa [55]. Moreover, for S. chartarum, a specific feature is the ability to produce extracellular dark pigment on a Czapek yeast extract agar (CYA) and MEA medium, respectively $[34,56]$. In our case this effect was the best visible on PDA + MEA, with the combination of media used in a ratio of 1:1 (Figure 1C1,C2).
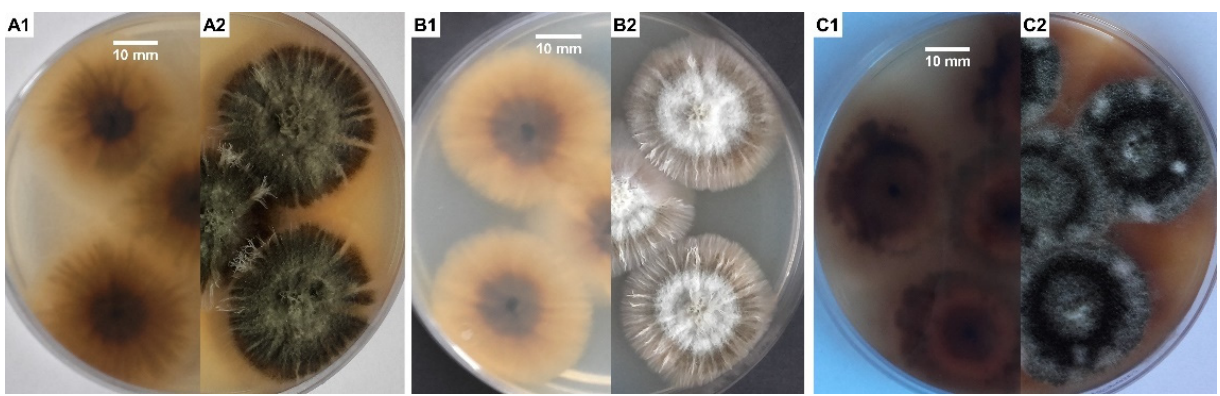

Figure 1. According to literature $[12,22,34,53,54,56]$, these images are typical for Stachybotrys chartarum morphology of colony after 10 days incubation at $25^{\circ} \mathrm{C}$ on the following: PDA medium (A1,A2); MEA (B1,B2); PDA + MEA, with the combination of media in a ratio of 1:1 (C1,C2), respectively, reverse/averse; strain isolated from gypsum board in flooded home, Cracow, Poland (S. chartarum MD1/2021). Photos by the author.

Microscopic features typical for S. chartarum anamorph (Figure 2A,B) are rich in melanin with regularly septate hyphae 2 to $4 \mu \mathrm{m}$ width on which olive-brown or olivegray conidiophores form, reaching a length of $30-70 \mu \mathrm{m}$ and a width of $3-5 \mu \mathrm{m}$. These are macronematous and mononematous, growing out solely and then erect or formed in groups as sympodially branched conidiophores. A mature conidiophore usually has a rough, slightly papillary surface in its upper part and is darker in color [12,31,57]. Conidiophores are usually septate, with 3-12 phialides radiating from the conidiophore apex. Mature conidiogenic cells are most often club shaped, narrower at the base and extended at the apex, smooth to verrucose and olive-brown, sometimes with slight collarettes. Onecelled aseptate conidia are typical ameroconidia and are generated by phialides individually and successively. These phialoconidia initially hyaline and smooth, become dark brown and thick walled with globose to a limoniform or cylindrical shape and sometimes with an apical hilum. Mature conidia are relatively large $(7-12 \mu \mathrm{m} \times 4-6 \mu \mathrm{m})$, usually bearing ornamentations and because of a sticky surface are clustered in heads [12,57]. It is commonly known that conidia are sticky and strongly adhere to surfaces because of a polysaccharide matrix that coats these structures, but its detailed composition remains undiscovered [58]. For this reason, the surface of colonies growing on mycological media as well on walls inside the buildings is wet and tarry black [59] The shape and ornamentation of conidia play a significant role in distinguishing S. chartarum strains from S. yunnaniensis [33] and 
S. chlorochalonata [34]. Conidia of the former, unlike those typical for S. chartarum, are cylindrical to semi-cylindrical. The morphological differences between S. chlorochalonata and $S$. chartarum are that the former forms smooth conidia and colonies with limited growth on CYA, and gives off a green extracellular pigment into the medium [15]. In conventional diagnostics the distinction between $S$. chartarum and other species of the Stachybotrys genus depends mainly on the shape, color, size and ornamentation of conidia. However, it should be borne in mind that the color and ornamentation of conidia changes with age; therefore, an attempt to identify young colonies lasting a few days may lead to misdiagnosis $[13,33,35,37]$. Memnoniella echinata was considered morphologically similar to S. chartarum, even to the extent that the taxonomic distinctions between the genera have been the subject of controversy in the past. On the other hand, these two species are significantly different in terms of metabolomes and spectrum of produced mycotoxins [60,61]. Unlike $S$. chartarum, where the conidia are concentrated in slime heads, in M. echinata the conidia are dry and arranged in long chains [38]. Contrary to the earlier statements, it is well known that conidia of $S$. chartarum are poorly adapted for dispersal by airspeeds that prevail inside houses, dwellings or public spaces [62].
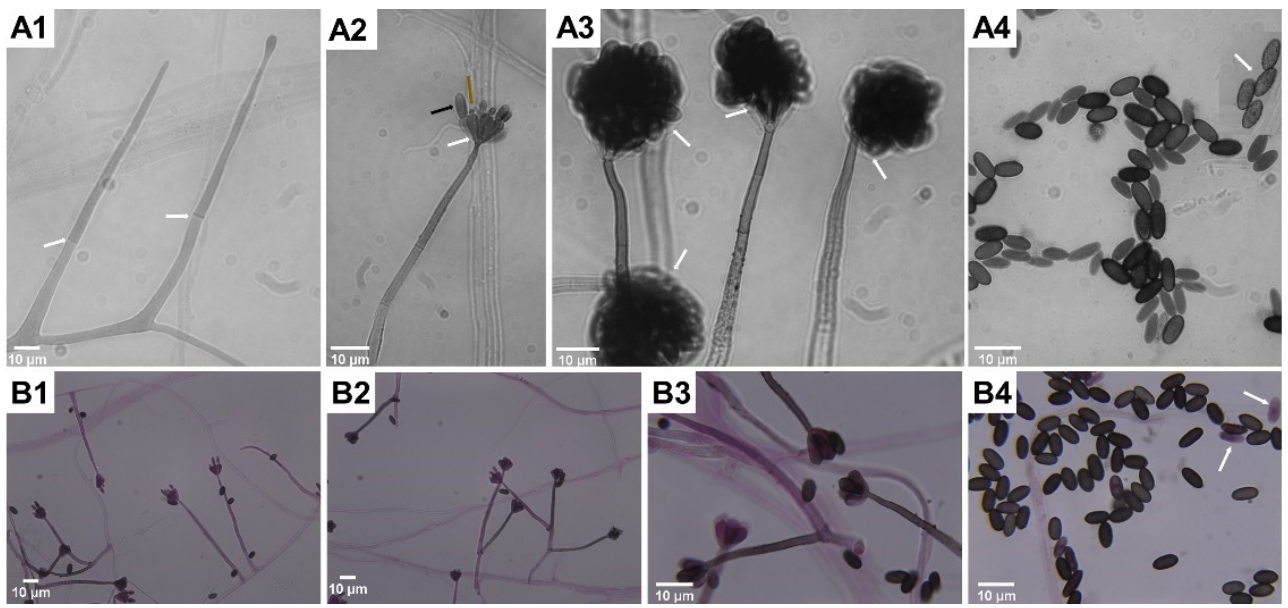

Figure 2. According to the literature $[12,13,31,34,35,37,57]$, these images represent Stachybotrys chartarum-specific mycelial structures typical for anamorphs visualized in light microscopy (saline wet mount microscopy, (A1-A4); fungal structures stained by lactofuchsin, (B1-B4)). Successive stages of development of mycelial structures: single, erect and septate (white arrows) conidiophores formation (A1); forming inverse bottle-shaped phialides (white arrow) with the apex (brown arrow) on top of conidiophore, successively produced single phialoconidia (black arrow, (A2)) clustered in slimy heads (white arrows, (A3)), which, when dried, release conidia (A4) with a rough surface (white arrow). Characteristic for S. chartarum formation of sympodially branched conidiophores (B2,B3), and less often formed solitary conidiophores (B1), release mature conidia that are black in color as opposed to immature conidia that easily absorb dye (white arrow, (B4)). Magnification 1000× (A1-A4,B3,B4) and $400 \times($ B1,B2), scale bars $10 \mu \mathrm{m}$. Photos by the author.

The teleomorphic stage of $S$. chartarum typically form eight-spored clavate asci inside subglobose to obpyriform perithecia consisting of a single layer. The mentioned fruit bodies usually occur solely and are rarely in pairs; they are black with a smooth surface. The ostiolar region is papillary but without periphyses. Additionally, thick-walled, septate and erect setae are irregularly distributed over the surface of perithecium. Ascospores or whole asci are released by ostiole, which poses a refractive apical ring. Typically through the ostioles, one-septate cylindrical ascospores are released with verrucose surfaces and with mucoid envelopes on the apices $[63,64]$. 


\section{Biological and Ecological Aspects}

S. chartarum is a typical saprophytic micromycete that has spread all over the world $[11,15]$. In natural environments this fungus feeds as saprophyte by decomposing cellulose and other dead plant matter; however, one work reported on its role in soybean invasion [65]. This black mold is able to grow in a range of $\mathrm{pH} 3.0-9.8$; however, the optimal $\mathrm{pH}$ for this fungus is in the range of 5.6-6.0. The optimal temperature for growth is in the range of $20-25{ }^{\circ} \mathrm{C}$, although this fungus can grow even at temperature $2.5^{\circ} \mathrm{C}[17,66]$. Moreover, Ochiai et al. [58] showed that none of 21 tested isolates of $S$. chartarum were able to grow at temperature above $37^{\circ} \mathrm{C}$. Although S. chartarum is capable of growing over a wide range of $\mathrm{pH}$ and temperatures, it is somewhat limited by the relative humidity (RH) of the air and associated with $\mathrm{RH} \mathrm{a}_{\mathrm{w}}$ values. This is one of the key parameters limiting growth indoors. It is well known that growth of $S$. chartarum at room temperature $\left(\sim 25^{\circ} \mathrm{C}\right)$ is possible with an $\mathrm{RH}$ value $\geq 93 \%$, and mycotoxin production by this fungus occurs at $\mathrm{a}_{\mathrm{w}} \geq 0.95[16,67]$. Both these values are higher than those known for other species of molds. Most fungi are able to actively grow at aw $\geq 0.85$, while xerophilic fungi, like those of the genus Aspergillus, Penicillium and Eurotium, are able to proliferate at or below a water activity (aw) of $0.85[68,69]$. An additional factor limiting the spread of S. chartarum and the colonization of new ecological niches is the limited ability of dissemination of its conidia in the air. This is due to the fact that, unlike Penicillium or Aspergillus, phialoconidia of this fungus are clustered in slime heads and mature conidia can be dispersed naturally after drying [11]. As it has already been shown experimentally, the release of conidia of S. chartarum is positively related to air flow rate, but negatively related to relative humidity [70]. Moreover, insects may play a role in spreading of conidia, as in case of other fungi [71]. However, drying is not a problem, and the fungus can survive unfavorable conditions and its conidia stay viable for years to decades [11]. Even if the water source runs out, S. chartarum may continue to propagate because of catabolic reactions, which provide additional water [72].

\section{Stachybotrys chartarum as a Biodeterioration Factor}

Indoor mold growth is a consequence of moisture from water damage, water leaks, condensation, water infiltration, improper RH prevailing in premises or flooding [19]. Mold growth begins when water is moistening porous materials for longer than a 48-h period [73]. However, so-called tertiary colonizers like S. chartarum require $\mathrm{a}_{\mathrm{w}}>0.9$ and $\mathrm{RH}>90 \%$ to grow [19] and constant moisture for active growth [20]. S. chartarum, due to its outstanding cellulolytic abilities and predisposition to develop on materials rich in cellulose [17,61], such as wood [3,74], fiberboard, gypsum board [75,76], polyurethanes [77], cellulose fabrics [77] and paper [78], is also the object of special attention as a biodeterioration factor [20,75]. S. chartarum, like the known species of the genus Chaetomium, belongs to the group of fungi often referred to as "soft rot fungi". These fungi cause changes in wooden building materials resulting in weight and stability losses of wood, albeit to a very limited extent compared to brown rot fungi [75]. S. chartarum, highly cellulolytic, is most often isolated from damp, improperly stored straw or hay, on the surface of which it occurs in the form of tarry-black colonies [79,80]. In houses with humidity problems, this fungus is most often isolated from various types of building materials, in particular from damp gypsum boards $[76,81,82]$ and wallpapers $[15,34]$. Like other molds, it often occurs in the areas of the so-called "thermal bridges" where water vapor condenses [83]. Although it thrives on cellulose-rich materials, it requires constant moisture for 10 to 12 days to start conidiation [66]. The intensive growth of colonies and the production of mycotoxins on moist material occur especially when the material rich in cellulose is also poor in nitrogen compounds [84]. S. chartarum as a hydrophilic species, is seen as a tertiary wall colonizer indoors, following the pioneering species, which are xerophilic and able to grow at aw $<0.8$ and $\mathrm{RH}<80 \%$ (especially of the genera Penicillium and Aspergillus, which are secondary colonizers able to grow at aw and RH in the range of $0.8-0.9$ and $80-90 \%$, respectively). The latter group includes such common species as Aspergillus flavus, Aspergillus versicolor, 
Cladosporium cladosporioides, Cladosporium sphaerospermum, Mucor circinelloides and Rhizopus oryzae [19].

\section{Harmful Effects on Humans and Animals Related to the Exposure to Stachybotrys chartarum}

S. chartarum was for many years perceived as an insignificant saprophyte [58]. The first cases of disease caused by this species are known from the area of present-day Ukraine. At that time, they were described in 1938 by Russian scientists, and concerned mainly farm animals, among which horses, being non-ruminants and more susceptible to trichothecenecontaminated feed, had the greatest ailments $[85,86]$. It is well known that $\mathrm{LD}_{50}$ in mammals for satratoxins, which are the most toxic among the trichothecenes, is $\sim 1 \mathrm{mg} / \mathrm{kg}$ of body weight [87]. The term stachybotryotoxicosis, which primarily refers to mycotoxin poisoning, was used then for this new disease $[88,89]$. Later, stachybotryotoxicosis was described on numerous farm animals from various parts of the world $[13,90,91]$. This disease entity was usually related with moldy hay and straw, often leading to mass deaths of animals [80,92]. This toxicosis in case of animals was characterized by symptoms, such as irritation of the mouth, throat and nose, as well as shock, dermal necrosis, hemorrhage, nervous disorder and cardiac arrhythmia, followed, when the disease persists, by lympha-denopathy with fever, leucopenia, agranulocytic anemia and finally death $[79,93,94]$. In cases of dead animals, autopsies revealed extensive ulcerations along the entire length of the gastrointestinal tract, degenerative changes in various organs and bone marrow [79]. It has also been shown that direct contact with the skin of a living or dead mycelial thallus provoked a dermatosis and also necrosis in a short time [95]. It was also suggested that a similar disease described in Siberia in 1934, characterized by similar changes as described above and significant mortality, was probably also stachybotryotoxicosis [79]. All the cases were related with direct contact of mycelial structures or secondary metabolites of this toxinogenic fungus with the skin and/or mucous membranes. Such contact was usually manifested by a strong inflammatory reaction and necrotic changes. Nevertheless, in all of these cases, active and invasive growth of hyphae was never observed in tissue.

In humans, the health aspects related with fungi of the Stachybotrys genus have been poorly described for a long time. Currently, we can find many reports in the literature on the harmful effects related with $S$. chartarum, which also were fatal $[9,58,96,97]$. So far, all the ailments in humans related with $S$. chartarum were associated with sick building syndrome in wet buildings $[9,98]$. Idiopathic pulmonary hemorrhage was for the first time reported in Greece [99]. However, S. chartarum as the most probable etiological agent of this disease was first isolated in Texas (USA) from the lungs of a child with typical symptoms [100]. Somewhat earlier, from January 1993 to December 1994, as many as 10 cases were described in the area of Cleveland (Ohio, USA) [101]. A total of 37 cases of pulmonary hemorrhage were described in 1993-1998, of which 12 were fatal [9,102]. These unusual cases of pulmonary hemorrhage, occurring mainly in children aged 1-8 months, were mainly manifested by cough with blood [9]. All patients came from damp or flooded homes, from which S. chartarum was abundantly isolated $[9,61]$. Although a study performed at this time by the CDC did not prove that $S$. chartarum was unambiguously responsible for pulmonary hemorrhage [103], studies conducted in other research centers during this period seemed to strongly suggest that this species was the etiological agent of acute pulmonary hemorrhage in the infants [9]. Nevertheless, the fact remains that, in 138 infants living in moldy homes in the United States, pulmonary hemorrhage was identified between 1993 and 1998 [9].

All of these disease symptoms were the result of the fungus' strong metabolic activity and exposure to its numerous secondary metabolites. The negative impact may not be the same due to the existence of two divergent phenotypes among strains of $S$. chartarum and due to the presence of specific secondary metabolite gene clusters in two mutually exclusive toxin chemotypes $[14,35,46]$.

It is commonly known that toxigenic fungi-produced mycotoxins can accumulate in all the fungal cells $[17,66]$. These secondary metabolites may accumulate in hyphae, 
conidiophores, phialides and conidia, which is also the case with S. chartarum [104,105]. These compounds may also diffuse into the medium on which the fungus grows $[17,66]$. Moreover, it was shown that secreted by $S$. chartarum guttation droplets also play a significant role in the exudation of mycotoxins into the air and surface on which this fungus grows [106]. Conidia of this fungus, due to the highest concentrations of mycotoxins they contain, are considered to be the most toxic $[66,107]$. It should be emphasized that in the case of satratoxins and atranones, these are produced in different amounts depending on chemotype [108] and genotype [46] of S. chartarum and conidia are the cells containing the highest concentrations of these mycotoxins [14]. Furthermore, it was confirmed that satratoxins are produced constitutively [107]. It explains why inhalation of mycotoxins and/or conidia released after the mentioned slime heads have dried, especially in the case of people who are constantly exposed to them, may cause serious damage to the lungs [58]. In the air of premises where S. chartarum grows on various types of finishing materials, a certain number of viable and dead conidia are always present. The latter, although are not able to grow on culture medium, still have strong allergic and toxic properties [11,17]. It is also commonly known that repeated exposure to dry, unextracted but viable $S$. chartarum conidia can induce pulmonary inflammation, arterial remodeling [109] and immune cell infiltration in mice inhaling them. This phenomenon was not observed for heat-inactivated conidia [110]. As it was observed, at four weeks after exposure, a T-helper cell type 2-mediated response was observed, and after 13 weeks, bronchoalveolar lavage (BAL) fluid was composed primarily of eosinophils, neutrophils and macrophages [109]. It is also worth noting that both dead and alive conidia aggressively irritate the skin and respiratory tract [111]. When conidia of $S$. chartarum enter the digestive system, symptoms such as burning in the mouth, nausea, vomiting, diarrhea and abdominal pain appear [112]. Conidia toxicity seems to be closely related to the concentrations of satratoxins present in them [61]. The ellipsoidal conidia of $S$. chartarum, $7-12 \mu \mathrm{m}$ by $4-6 \mu \mathrm{m}$ in size, seemingly appear too large to enter the respiratory tract. However, their aerodynamic diameter is around $5 \mu \mathrm{m}$. Achieving such a small diameter is possible because the fibers or ellipsoidal particles orient themselves "longitudinally" in the air, in such a way that their aerodynamic diameter corresponds to this narrower dimension [61]. All the adverse effects of S. chartarum on human health are taken together in Table 2.

Concerning pathogenicity of S. chartarum and looking through the prism of the fatal or life-threatening cases of pulmonary hemorrhage most possibly caused by S. chartarum documented in the literature, it is necessary to answer one of the important questions. What features or virulence factors support the assigning this species in the rank of filamentous pathogenic fungi? At the moment, one of the most urgent issues should be to clarify these virulence factors using in vivo studies performed in animal models. Namely, is S. chartarum capable of growing in lung tissue or other solid organs at typical for mammals average body temperature? It is also worthy to consider if all the described fatal cases in the literature $[9,21,60,99-103,119,120]$ were directly related to household exposure to an extremally dangerous mycotoxins, mainly satratoxins, produced by this fungus or related with the active growth of this fungus within infected lung tissue. This should be also specified and supported by photographic documentation if lung tissues observed posthumously were invaded by pigmented, dark, regularly septated hyphae like in typical cases of phaeohyphomycosis. Actually, we know many species of fungi like dermatophytes, which, excluding T. verrucosum, are incapable of growing at a temperature $\geq 37^{\circ} \mathrm{C}$, but can invade skin, hairs or nails causing superficial mycoses [121]. In the subject literature, so far we can find only one case report on S. chartarum infection of the scalp in an 80-year-old immunocompetent male (with no history of pulmonary mycotoxicosis) [122], which, according to the definition, belongs to the category of superficial fungal infections. It should be noted that this case report is poorly documented from the clinical and laboratory side. First of all, such infection should be confirmed by a positive direct microscopical examination of skin scrapings or a positive histological specimen to prove invasive fungal growth in skin tissue. Moreover, the declared etiological factor has not been molecularly identified and the photo- 
graphic documentations posted within this publication were borrowed from other sources instead of clinical images of infection in the case of the considered patient. Moreover, as the authors declared, an 80-year-old male was treated with amphotericin B for a year, which, when long-term administered orally or intravenously, usually shows many side effects and is a burden for the patient [123]. A recently published work [124], the first case report on invasive Stachybotrys chlorohalonata sinusitis that established a 23-year-old male with refractory acute lymphocytic leukemia, appears to be much better documented. The authors declared invasive growth of the fungus, which was confirmed by histopathology and immunohistochemistry (IHC), and the etiological factor was identified according to molecular biology methods including multi-locus sequence typing. However, it should be noted that out of the three sine biopsy tissues, only the first seems to suggest the presence of $S$. chlorohalonata as the etiological agent of this infection. The second sinus biopsy was negative, indicating that the clinical material tested was microbiologically sterile. Finally, the third biopsy performed showed the presence of Aspergillus calidoustus as an etiological factor of invasive fungal sinusitis. This species was previously identified as the closely related Aspergillus ustus, but unlike A. ustus, A. calidoustus grows well at or above $37^{\circ} \mathrm{C}$ [125]. Moreover, given the growing number of scientific reports on its role as etiological factor of invasive fungal infections, this species is considered as emerging pathogen [125-127]. Taken together, it cannot be ruled out that the causative agent of invasive fungal sinusitis in this case was $A$. calidoustus, and some symptoms were aggravated and more complicated by the presence of $S$. chlorohalonata, for which observed germination of conidia could also be possible and was also described previously in the literature [128]. It cannot be excluded that $A$. calidoustus was the primary and main etiological factor of described invasive fungal sinusitis. This is evidenced by the absence of dark pigmented conidia typical for S. chlorohalonata (not present on Figure 5 included in the discussed paper) [124]. Observed hyphal elements with vesicular swellings in the histological slides obtained from the first and third biopsies were brown pigmented, which is also typical for A. calidoustus [125]. Finally, genomic DNA extraction was performed each time from the obtained pure cultures and not directly from the clinical material.

On the other hand, in accordance with the postulates of Koch, each etiological factor of infection should be isolated and able to develop fully symptomatic disease in another healthy susceptible host [129]. To the best of actual knowledge on the subject of $S$. chartarum-related diseases, the aforementioned Koch postulates seem impossible to meet for many reasons. Knowing that this fungus is easily cultivable in vitro, it would seem that every disease entity most likely related to $S$. chartarum, and especially those like pulmonary hemorrhage, can be clearly confirmed by isolating the elements of this fungus from tissues. According to the literature $[9,39,119]$, it is commonly known that acute pulmonary hemorrhage and any other complaints related to exposure to $S$. chartarum mycotoxins, VOC and allergenic compounds cannot be interpreted in accordance with Koch's postulates. It is well known that some of the disease entities undeniably related to $S$. chartarum can be induced by dead conidia and other mycelial structures [11,17], which cannot give rise to new colonies. Moreover, many symptoms accompanying the disease entities caused by S. chartarum are simply related to mycotoxins $[3,8,102,117,130]$ and also can be associated with hyper inflammation [131]. Thus, isolation of $S$. chartarum will not be possible and Koch's postulates cannot be met. 
Table 2. Negative aspects related to the presence of $S$. chartarum in homes and dwellings *.

\begin{tabular}{|c|c|c|c|}
\hline Mycotoxins & MVOCs \# & Allergens & $\begin{array}{l}\text { Ailments Related with Direct or } \\
\text { Indirect Exposure to } \\
\text { S. chartarum }{ }^{\wedge}\end{array}$ \\
\hline 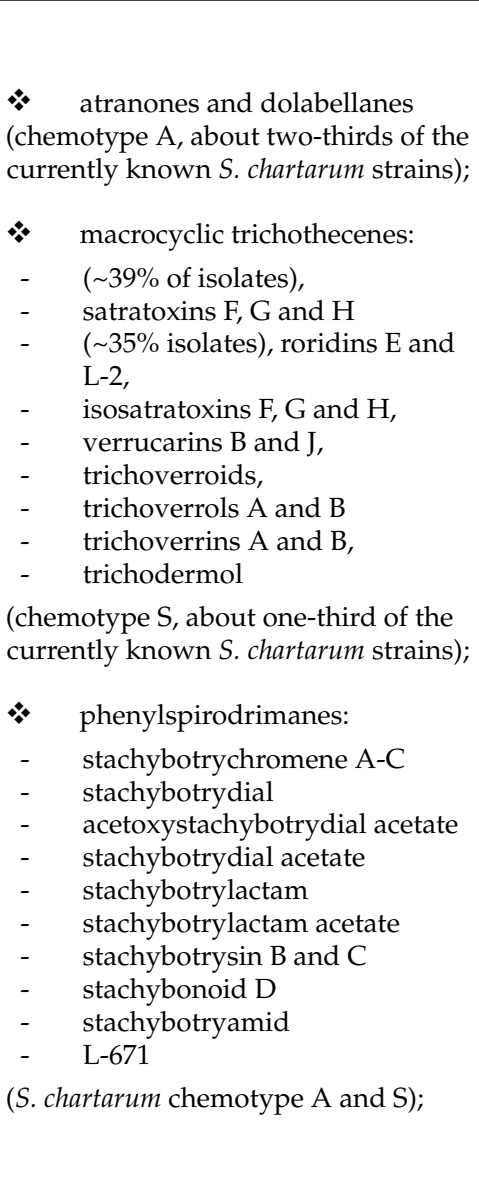 & $\begin{array}{l}\text { triprenylated phenolics; } \\
\text { trichodiene; acetone; } \\
\text { 2-propanol; } \\
\text { 1-propanol; } \\
\text { 2-metyl-1-propanol; } \\
\text { 1-butanol; } \\
\text { 2-butanol; } \\
\text { 2-methyl-3-buten-2-ol; } \\
\text { 3-methyl-1-butanol; } \\
\text { 3-methyl-2-butanol; } \\
\text { thujopsene; } \\
\text { 2-ethylhexanol; } \\
\text { 2-ethylhexyl acetate; } \\
\text { methyl benzoate; } \\
\text { C15 RI1485 13-farnesene; } \\
\text { C15 RI 1513 } \alpha \text {-curcumene; } \\
\text { C15 RI 1519 } \beta \text {-bisabolene; } \\
\text { C15 RI 1544 trichodiene; } \\
\text { C15 RI 1545 cuparene; } \\
\text { sesquiterpenes; } \\
\text { 2-ethylhexanol; } \\
\text { 3-methylfuran; } \\
\text { dimethylhexadiene; } \\
\text { dimethyl } \\
\text { disulfide; } \\
\text { 1-hexanol; } \\
\text { 1-octanol; } \\
\text { anisole; } \\
\text { 2- and 3-methylanisole; } \\
\text { sesquiterpene hydrocarbons; }\end{array}$ & $\begin{array}{l}\text { Sta c } 3 \text { ( } 21 \text { kDa protein, } 144 \\
\text { aminoacids), extracellular alkaline } \\
\text { Mg-dependent } \\
\text { exodesoxyribonuclease, IgE } \\
\text { inducing; } \\
34 \text { kDa unknown secretory } \\
\text { protein (SchS34 open reading } \\
\text { frame encodes protein of } 221 \\
\text { amino acids in length), localized } \\
\text { on surface of conidia; } \\
\text { stachyrase A (chymotrypsin-like } \\
\text { serine proteinase); } \\
\text { aspartyl- and metalloproteases; } \\
\text { peroxisomal membrane protein; } \\
\text { thioredoxin; } \\
\text { glutathione reductase; } \\
\text { Mn-superoxide dismutase; } \\
\text { cyclophilins; } \\
\text { heat shock proteins; } \\
\text { enolase; } \\
\text { alcohol- and aldehyde } \\
\text { dehydrogenases; } \\
\text { glycosidases; } \\
\text { chitin; } \\
\text { glycoproteins; } \\
\beta-1,3-D-g l u c a n ;\end{array}$ & $\begin{array}{l}\text { pulmonary hemorrhage **; } \\
\text { gastrointestinal hemorrhage }{ }^{* *} \text {; } \\
\text { sick building syndrome (SBS); } \\
\text { mycotoxicosis } \\
\text { (stachybotrytoxicosis); } \\
\text { leucopenia; } \\
\text { lymphadenopathy; } \\
\text { agranulocytic anemia; } \\
\text { asthma; } \\
\text { adult nasal and tracheal bleeding; } \\
\text { allergies; } \\
\text { inflammation; } \\
\text { lung injury; } \\
\text { pulmonary } \\
\text { hypertension; } \\
\text { pulmonary arterial remodeling; } \\
\text { irritation and necrotic changes } \\
\text { within skin and/or } \\
\text { mucous membranes; } \\
\text { hypersensitivity pneumonitis } \\
\text { (repeated inhalation of conidia); } \\
\text { neurotoxicity (induction of } \\
\text { apoptosis of olfactory sensory } \\
\text { neurons (OSNs) in the } \\
\text { olfactory epithelium); } \\
\text { inhibitory activity } \\
\text { against the complement system } \\
\text { (K-76-phenylspirodrimane } \\
\text { derivative and its oxidation } \\
\text { product, K-76 COOH); } \\
\text { headache; } \\
\text { fatigue; } \\
\text { cough; } \\
\text { burning nasal passages; tightness } \\
\text { of chest; } \\
\text { muscle and stomach aches, }\end{array}$ \\
\hline
\end{tabular}

* prepared based on the subject literature [13,14,21,25,96,102,113-118]; \# MVOCs-microbial volatile organic compounds; ^ documented and the most possible; ${ }^{* *}$ considered as related with proteins with emolysin and proteinase activities and stachylysin (hemolysin with hemolytic activity, localized in the inner cell wall of spores and mycelia).

The recent study from 2007 [62] shows that $S$. chartarum is poorly adapted for dispersal by airspeeds that prevail in the indoor environment opposite to Aspergillus fumigatus, the most common etiological factor of aspergillosis [132]. While the last mentioned conidia can be easily dispersed because they are tiny (ca 2.5-3.5 $\mu \mathrm{m}$ in diameter) and capable of entering the alveoli [132], only modest numbers of conidia will become airborne in the case of S. chartarum, even in heavily contaminated homes [62]. Moreover, in the context of S. chartarum having the potential to invade the lung tissue, it was recently shown that this species is not able to grow well enough at $37^{\circ} \mathrm{C}$, and this is the maximum temperature for growth of this fungus [58]. It was demonstrated in this study that none out of the 21 isolates tested were able to grow at $38^{\circ} \mathrm{C}$ or higher [58]. The authors observed that none of the conidia in the lungs were able to germinate, which allowed them to conclude that S. chartarum has no possibility to invade lung tissues. So far, only one paper has described growth of $S$. chartarum in the lungs of rats. Nevertheless, this could be possible because of the immunological status of 4-day-old rats, which in this case would have been immature, hence the inflammatory effect was not developed and germination of conidia in lung tissue was possible [128]. Anyway, as the authors of this work finally stated, S. chartarum, even in the immature rat puppies, was not able to establish an effective infection [128]. So, what constitutes the serious risk for humans and animals with long-term exposure to the black fungus $S$. chartarum, even though it is not similar to typical pathogenic black filamentous 
fungi? Depending on the strains, $S$. chartarum is capable of producing various types of secondary metabolites, in particular trichothecenes, including the following: trichoverroidin derivatives, roridin $\mathrm{E}$ and $\mathrm{L}-2$; satratoxin $\mathrm{F}, \mathrm{G}$ and $\mathrm{H}$; isosatratoxin $\mathrm{F}, \mathrm{G}$ and $\mathrm{H}$; verrukarin $\mathrm{B}$ and J; verrukarol; trichoverroid; trichoverol A and B; or trichoverrin A and B, etc. [17,89]. It is well known that, so far, all the tested $S$. chartarum strains are able to produce the immunosuppressive phenylspirodrimanes, and the most cytotoxic macrocyclic trichothecenes are generated only by the genotype $S$ of $S$. chartarum [133]. Moreover, this black mold is characterized by a strong proteolytic activity [118]. It should be emphasized that the most dangerous satratoxins are generally produced in much greater amounts than the other trichothecenes [89,134]. It was shown that satratoxin $\mathrm{H}$ is always the main toxin produced during the growth of this fungus on wallpaper and its concentration can reach significantly higher values during the growth on this substrate compared to concentrations achieved during the growth on fir and fiberglass [134]. Moreover, many strains of this species produce A-G atranones, whose influence on human health has not been fully elucidated yet $[102,135]$. This black mold produces factors inducing acute pulmonary hemorrhage and the very toxic 7-triprenyl phenol-type sesquiterpenoid derivatives, which are tyrosine kinase inhibitors [94]. In turn, the released proteinases, hemolysins and $\beta$-glucan, can cause a number of pathophysiological effects. This fungus is also able to produce stachylysin, a hemolytic protein that breaks down erythrocytes [136]. Exposure to S. chartarum structures of mycelium is extremely dangerous for newborns less than 6 months of age, typically leading to pulmonary hemorrhage $[119,137]$. It was also proven that both satratoxins as atranones can induce DNA damage leading to cell death in THP-1 cells [138]. Nowadays, we have more and more evidence to conclude that $S$. chartarum carries the potential to cause a serious acute inflammatory response mainly via PMNs in alveoli and the peribronchiolar space. It is well known that repeated exposure to conidia of this fungus resulted in increased eosinophilic infiltration into perivascular tissues and proximal alveoli [58].

Even with such a large amount of evidence on the extremely harmful properties of this species, $S$. chartarum was not included as a dangerous species on the list prepared in 1996 by the European Confederation of Medical Mycology (ECMM), which classified micromycete fungi according to biosafety levels (BSL) [139]. As noted by other experts in this topic [140], at the same time and on the list drawn up in the same year by the American Industrial Hygiene Association (AIHA) organization, this fungus ranks first among molds producing mycotoxins that are harmful to human health. It was also suggested [140] that due to the danger of mycotoxins in the trichothecene group (satratoxins, atranones and roridin), S. chartarum should be placed in the BSL-2 class due to the secondary metabolites secreted by this species. In accordance with the adopted division, this species would be in the same group of fungi as such opportunistic pathogens as: Aspergillus flavus, Candida albicans or Acremonium kiliense $[139,140]$. On the other hand, it is commonly known that living or working in moldy indoor environments is usually associated with sick building syndrome (SBS) or other ailments. It is possible that many of the so far described cases that pose a threat to life and health related to $S$. chartarum were rather related to building-associated molds, comprising many species that colonize wet or damp building materials [141]. As stated by Miller et al. [96], there is limited evidence that severe lung changes and neurocognitive damage, respectively, can occur from building exposure to $S$. chartarum. Although there are still studies suggesting a significant threat posed by S. chartarum to human health and life and even its pathogenicity $[11,85,98,128]$, the clinical significance of this fungus is contested $[96,117]$.

\section{Antifungal Agents to Eradicate S. chartarum from Indoor Environments}

To eliminate the adverse effects of mold on human and animal health, contaminated interior areas should be carefully cleaned with anti-molding preparations such as common bleach $[142,143]$. The process of eradicating of molds includes removing the contaminated building material and then applying a fungicide to the surface that has had any contact with molding areas. Preventive steps have to be taken to eliminate the development of 
moisture, which is the main factor promoting fungal growth [144]. Fungicides used indoors should be non-toxic, hypoallergenic, odorless and non-volatile. Additionally, in environments that can promote fungal growth, like those where it is difficult to establish or control relative humidity $(\mathrm{RH})$, the chemical agents should provide long-term protection [145]. A frequently recommended mildew remover from indoor spaces is the common household bleach, whose active agent is sodium hypochlorite [142,143]. Sodium hypochlorite is a protein-denaturing agent [146]. It is a common disinfectant that is effective against bacteria and fungi $[143,147,148]$. Essentially, 2.4\% sodium hypochlorite kills mold and they become uncultivable, but importantly, it also reduces levels of allergens produced by spores [142,143]. This ability is also confirmed by its fragmentation of household allergens [149]. Hypochlorite can be used in the homes of asthma sufferers because it does not worsen breathing parameters; on the contrary, by reducing allergens, the symptoms of the disease are also reduced [150]. Commonly available disinfectants are also used to remove mold. Effective preparations are based on quaternary ammonium chloride compounds, non-ionic surfactants, chelating agents or those containing phenol and glutaraldehyde. Hydrogen peroxide (17\%) and isopropyl alcohol (70\%) are also effective [144,151]. Actually, many mold-remediation guidance documents are available, reviewed in a book published by Committee On Damp Indoor Spaces and Health [152]. Antimicrobial paints are also commercially available. These can even be used on mold-contaminated gypsum wallboard that cannot be replaced despite recommendations. Paints of this type are applied to dry surfaces previously cleaned with water or bleach. Depending on the manufacturer, the main active ingredients in said paints include calcium hydroxide, titanium dioxide, chlorothalonil or diiodomethyl p-tolyl sulfone [153]. Alternative, "natural" methods of mold control are being sought. Plant essential oils are an example [154]. Essential oils are mixtures of volatile compounds synthesized by plants, among which are terpenes and terpenoids as well as aliphatic and aromatic components, and are characterized by low molecular weight [155]. It is also known that extracts of Thymus vulgaris have a pronounced antifungal effect on S. chartarum [156], but there is also one report on its isolation from the dried tissues of this plant [157], which rather suggests the contamination of harvested herbs and secondary colonization by this toxic mold. Tea tree oil (Melaleuca alternifolia) also shows antifungal properties against some black molds including $S$. chartarum [158]. We currently have a lot of information on the antifungal activity of essential oils toward $S$. chartarum, but still the main problem is related with the ability to compare obtained results because of lack of standard protocols for testing in vitro biological activity of plant oils. Additionally, most are laboratory-based and in situ studies, and those performed in indoor spaces are lacking (including environmental factors) [154]. Moreover, it is also worthy to consider whether essential oils will be as cost effective as bleach. Furthermore, another important gap in our knowledge so far is the effects of essential oils on the health of people with sick building syndrome, which could possibly exacerbate the disease symptoms.

\section{Conclusions}

The research problem related to this fungus seems to be not overly publicized, and there is still demand to truthfully define the real threats of $S$. chartarum and phylogenetically related species. Although there are currently about 500 publications on Stachybotrys spp., there are still some gaps in our knowledge that could constitute important areas for further research. The most important problem, which should be fully elucidated as soon as possible, remains the clarification of the pathogenicity of Stachybotrys chartarum and related species, such as $S$. chlorohalonata. Actually, we know that none of the $S$. chartarum strains tested so far were able to grow at a temperature $\geq 37^{\circ} \mathrm{C}$, which makes it even more important to clearly determine whether invasive growth inside the mammal body and tissue penetration by hyphae of this black fungus is possible. Even if it is not possible due to the temperature, which inhibits growth, it should be determined whether superficial infections of the skin, nails, etc. are likely to occur. In the light of the currently available data, it is highly probable that all the changes in internal organs described so far, including gastrointestinal and 
pulmonary hemorrhage, as well as necrotic changes on the skin or mucous membranes, are simply related to secondary metabolites of this fungus, including mycotoxins. Certainly, the answer to these questions will require appropriate in vivo experiments on suitable animal models, considering both fully immunocompetent individuals as well as in various levels of immunosuppression, or with defects in the immune system. The issue of developing the tests, which will need to be quick, cheap and specific in detection of Stachybotrys spp. in dwellings, seems to be equally important. Certainly, many of these issues will be clarified and more light will be shed on these bothering issues as the S. chartarum genome is fully annotated and the secondary metabolism pathways and metabolome of this black toxic mold are better known. Last but not least, it seems important to us to draw attention to the need to use more precise terminology in the context of well-documented pulmonary or gastrointestinal hemorrhage cases described in the literature, undeniably related to species of the genus Stachybotrys. This seems justified because we currently have a wide range of diagnostic tools to confirm Stachybotrys-induced pulmonary hemorrhage (SIPH) or Stachybotrys-induced gastrointestinal hemorrhage (SIGH).

Author Contributions: Conceptualization, writing-original draft preparation, supervision, preparation of photographic documentation (M.D.); formal analysis, editing, literature formatting (K.S.); writing—review and editing (J.Z.); formal analysis, visualization (D.Ł.); writing—review and editing, supervision (S.G.). All authors have read and agreed to the published version of the manuscript.

Funding: This research has been made possible by the Kosciuszko Foundation. The American Centre of Polish Culture.

Institutional Review Board Statement: Not applicable.

Informed Consent Statement: Not applicable.

Data Availability Statement: Not applicable.

Acknowledgments: The authors would like to thank Małgorzata Bień, (University of Wroclaw) for critical reading of the manuscript and all the valuable comments.

Conflicts of Interest: The authors report no conflict of interest. The authors alone are responsible for the content and writing of the paper.

\section{References}

1. Wu, F.; Jacobs, D.; Mitchell, C.; Miller, D.; Karol, M.H. Improving Indoor Environmental Quality for Public Health: Impediments and Policy Recommendations. Environ. Health Perspect. 2007, 115, 953-957. [CrossRef] [PubMed]

2. Montgomery, D.D.; Kalman, D.A. Indoor/Outdoor Air Quality: Reference Pollutant Concentrations in Complaint-Free Residences. Appl. Ind. Hyg. 1989, 4, 17-20. [CrossRef]

3. Miller, J.D.; McMullin, D.R. Fungal Secondary Metabolites as Harmful Indoor Air Contaminants: 10 Years on. Appl. Microbiol. Biotechnol. 2014, 98, 9953-9966. [CrossRef] [PubMed]

4. Wolf, M.; Lai, P.S. Indoor Microbial Exposures and Chronic Lung Disease: From Microbial Toxins to the Microbiome. Clin. Chest Med. 2020, 41, 777-796. [CrossRef] [PubMed]

5. Chew, G.L.; Horner, W.E.; Kennedy, K.; Grimes, C.; Barnes, C.S.; Phipatanakul, W.; Larenas-Linnemann, D.; Miller, J.D.; Workgroup, E.A. Procedures to Assist Health Care Providers to Determine When Home Assessments for Potential Mold Exposure Are Warranted. J. Allergy Clin. Immunol. Pract. 2016, 4, 417-422.e2. [CrossRef]

6. Daisey, J.M.; Angell, W.J.; Apte, M.G. Indoor Air Quality, Ventilation and Health Symptoms in Schools: An Analysis of Existing Information. Indoor Air 2003, 13, 53-64. [CrossRef]

7. Laumbach, R.J.; Kipen, H.M. Bioaerosols and Sick Building Syndrome: Particles, Inflammation, and Allergy. Curr. Opin. Allergy Clin. Immunol. 2005, 5, 135-139. [CrossRef]

8. Joshi, S.M. The Sick Building Syndrome. Indian J. Occup. Environ. Med. 2008, 12, 61-64. [CrossRef]

9. Dearborn, D.G.; Yike, I.; Sorenson, W.G.; Miller, M.J.; Etzel, R.A. Overview of Investigations into Pulmonary Hemorrhage among Infants in Cleveland, Ohio. Environ. Health Perspect. 1999, 107 (Suppl. 3), 495-499. [CrossRef]

10. Chapman, J.A. Stachybotrys chartarum (Chartarum = Atra = Alternans) and Other Problems Caused by Allergenic Fungi. Allergy Asthma Proc. 2003, 24, 1-7.

11. Hossain, M.A.; Ahmed, M.S.; Ghannoum, M.A. Attributes of Stachybotrys chartarum and Its Association with Human Disease. J. Allergy Clin. Immunol. 2004, 113, 200-208, Quiz 209. [CrossRef] 
12. Lombard, L.; Houbraken, J.; Decock, C.; Samson, R.A.; Meijer, M.; Réblová, M.; Groenewald, J.Z.; Crous, P.W. Generic HyperDiversity in Stachybotriaceae. Pers. Mol. Phylogeny Evol. Fungi 2016, 36, 156-246. [CrossRef]

13. Wang, Y.; Hyde, K.D.; McKenzie, E.H.C.; Jiang, Y.-L.; Li, D.-W.; Zhao, D.-G. Overview of Stachybotrys (Memnoniella) and Current Species Status. Fungal Divers. 2015, 71, 17-83. [CrossRef]

14. Semeiks, J.; Borek, D.; Otwinowski, Z.; Grishin, N.V. Comparative Genome Sequencing Reveals Chemotype-Specific Gene Clusters in the Toxigenic Black Mold Stachybotrys. BMC Genom. 2014, 15, 590. [CrossRef]

15. Li, D.-W.; Yang, C.S. Taxonomic History and Current Status of Stachybotrys chartarum and Related Species. Indoor Air 2005, 15 (Suppl. 9), 5-10. [CrossRef] [PubMed]

16. Grant, C.; Hunter, C.A.; Flannigan, B.; Bravery, A.F. The Moisture Requirements of Moulds Isolated from Domestic Dwellings. Int. Biodeterior. 1989, 25, 259-284. [CrossRef]

17. Piecková, E.; Jesenská, Z. Microscopic Fungi in Dwellings and Their Health Implications in Humans. Ann. Agric. Environ. Med. 1999, 6, 1-11. [PubMed]

18. Menneer, T.; Mueller, M.; Sharpe, R.A.; Townley, S. Modelling Mould Growth in Domestic Environments Using Relative Humidity and Temperature. Build. Environ. 2022, 208, 108583. [CrossRef]

19. D'Orazio, M. 12-Materials Prone to Mould Growth. In Woodhead Publishing Series in Civil and Structural Engineering; PachecoTorgal, F., Jalali, S., Fucic, A., Eds.; Woodhead Publishing: Cambridge, UK, 2012; pp. 334-350. [CrossRef]

20. Andersen, B.; Nissen, A.T. Evaluation of Media for Detection of Stachybotrys and Chaetomium Species Associated with WaterDamaged Buildings. Int. Biodeterior. Biodegrad. 2000, 46, 111-116. [CrossRef]

21. Jagels, A.; Lindemann, V.; Ulrich, S.; Gottschalk, C.; Cramer, B.; Hübner, F.; Gareis, M.; Humpf, H.-U. Exploring Secondary Metabolite Profiles of Stachybotrys spp. by LC-MS/MS. Toxins 2019, 11, 133. [CrossRef]

22. Jarvis, B.B.; Hinkley, S.F.; Nielsen, K.F. Stachybotrys: An Unusual Mold Associated with Water-Damaged Buildings. Mycotoxin Res. 2000, 16, 105-108. [CrossRef] [PubMed]

23. Yang, B.; He, Y.; Lin, S.; Zhang, J.; Li, H.; Wang, J.; Hu, Z.; Zhang, Y. Antimicrobial Dolabellanes and Atranones from a Marine-Derived Strain of the Toxigenic Fungus Stachybotrys chartarum. J. Nat. Prod. 2019, 82, 1923-1929. [CrossRef] [PubMed]

24. MMWR Staff. CDC. Update: Pulmonary Hemorrhage/Hemosiderosis among Infants—Cleveland, Ohio. Available online: https:/ / www.cdc.gov/mmwr/preview/mmwrhtml/mm4909a3.htm (accessed on 7 January 2022).

25. Yike, I.; Dearborn, D. Guest Editorial-Novel Insights into the Pathology of Stachybotrys chartarum. Mycopathologia 2011, 172, 1-3. [CrossRef]

26. Hyde, K.D.; Al-Hatmi, A.M.S.; Andersen, B.; Boekhout, T.; Buzina, W.; Dawson, T.L.; Eastwood, D.C.; Jones, E.B.G.; de Hoog, S.; Kang, Y.; et al. The World's Ten Most Feared Fungi. Fungal Divers. 2018, 93, 161-194. [CrossRef]

27. Hughes, S.J. Revisiones Hyphomycetum Aliquot Cum Appen-Dice de Nominibus Rejiciendis. Can. J. Bot. 1958, 36, 727-836. [CrossRef]

28. Notices, B. Icones Fungorum Hucusque Cognitorum. Auctore A. C. J. Corda. Pragæ, 1837. Ann. Mag. Nat. Hist. 1838, 2, 61-63. [CrossRef]

29. MYCOBANK Database. Available online: https:/ /www.mycobank.org/ (accessed on 14 February 2022).

30. Species Fungorum. Available online: http:/ / www.speciesfungorum.org/Names/SynSpecies.asp?RecordID=306362 (accessed on 14 February 2022).

31. Bisby, G.R. Stachybotrys. Trans. Br. Mycol. Soc. 1943, 26, 133-143. [CrossRef]

32. Koster, B.; Scott, J.; Wong, B.; Malloch, D.; Straus, N. A Geographically Diverse Set of Isolates Indicates Two Phylogenetic Lineages within Stachybotrys chartarum. Can. J. Bot. 2003, 81, 633-643. [CrossRef]

33. Kong, H. Stachybotrys yunnanensis sp. Nov. and Neosartorya delicata sp. Nov. Isolated from Yunnan, China. Mycotaxon 1997, 62, 427-434.

34. Andersen, B.; Nielsen, K.F.; Jarvis, B.B. Characterization of Stachybotrys from Water-Damaged Buildings Based on Morphology, Growth, and Metabolite Production. Mycologia 2002, 94, 392-403. [CrossRef]

35. Andersen, B.; Nielsen, K.F.; Thrane, U.; Szaro, T.; Taylor, J.W.; Jarvis, B.B. Molecular and Phenotypic Descriptions of Stachybotrys chlorohalonata sp. Nov. and Two Chemotypes of Stachybotrys chartarum Found in Water-Damaged Buildings. Mycologia 2003, 95, 1227-1238. [CrossRef]

36. Wiederhold, N.P.; Sutton, D.A.; Li, D.-W.; Liang, Y.; Thompson, E.H.; Wickes, B.L.; Herrera, M.L.; Rhoads, S.L.; Mortensen, J.E. Stachybotrys eucylindrospora Isolated from Foreign Material Following a Traumatic Eye Injury. Mycoses 2014, 57, 437-441. [CrossRef] [PubMed]

37. Jong, S.C.; Davis, E.E. Contribution to the Knowledge of Stachybotryis and Memnoniella in Culture. Mycotaxon 1976, 3, $409-485$.

38. Haugland, R.A.; Vesper, S.J.; Harmon, S.M. Phylogenetic Relationships of Memnoniella and Stachybotrys Species and Evaluation of Morphological Features for Memnoniella Species Identification. Mycologia 2001, 93, 54-65. [CrossRef]

39. Vesper, S.; Dearborn, D.G.; Yike, I.; Allan, T.; Sobolewski, J.; Hinkley, S.F.; Jarvis, B.B.; Haugland, R.A. Evaluation of Stachybotrys chartarum in the House of an Infant with Pulmonary Hemorrhage: Quantitative Assessment before, during, and after Remediation. J. Urban Health 2000, 77, 68-85. [CrossRef] [PubMed]

40. Cruse, M.; Telerant, R.; Gallagher, T.; Lee, T.; Taylor, J.W. Cryptic Species in Stachybotrys chartarum. Mycologia 2002, 94, 814-822. [CrossRef] [PubMed] 
41. Köck, J.; Gottschalk, C.; Ulrich, S.; Schwaiger, K.; Gareis, M.; Niessen, L. Rapid and Selective Detection of Macrocyclic Trichothecene Producing Stachybotrys chartarum Strains by Loop-Mediated Isothermal Amplification (LAMP). Anal. Bioanal. Chem. 2021, 413, 4801-4813. [CrossRef] [PubMed]

42. Stielow, J.B.; Lévesque, C.A.; Seifert, K.A.; Meyer, W.; Iriny, L.; Smits, D.; Renfurm, R.; Verkley, G.J.M.; Groenewald, M.; Chaduli, D.; et al. One Fungus, Which Genes? Development and Assessment of Universal Primers for Potential Secondary Fungal DNA Barcodes. Pers. Mol. Phylogeny Evol. Fungi 2015, 35, 242-263. [CrossRef]

43. Lewińska, A.M.; Peuhkuri, R.H.; Rode, C.; Andersen, B.; Hoof, J.B. Rapid Detection and Identification of Stachybotrys and Chaetomium Species Using Tissue PCR Analysis. J. Microbiol. Methods 2016, 130, 115-122. [CrossRef]

44. Ulrich, S.; Biermaier, B.; Bader, O.; Wolf, G.; Straubinger, R.K.; Didier, A.; Sperner, B.; Schwaiger, K.; Gareis, M.; Gottschalk, C. Identification of Stachybotrys spp. by MALDI-TOF Mass Spectrometry. Anal. Bioanal. Chem. 2016, 408, 7565-7581. [CrossRef]

45. Gruenwald, M.; Rabenstein, A.; Remesch, M.; Kuever, J. MALDI-TOF Mass Spectrometry Fingerprinting: A Diagnostic Tool to Differentiate Dematiaceous Fungi Stachybotrys chartarum and Stachybotrys chlorohalonata. J. Microbiol. Methods 2015, 115, 83-88. [CrossRef] [PubMed]

46. Ulrich, S.; Niessen, L.; Ekruth, J.; Schäfer, C.; Kaltner, F.; Gottschalk, C. Truncated Satratoxin Gene Clusters in Selected Isolates of the Atranone Chemotype of Stachybotrys chartarum (Ehrenb.) S. Hughes. Mycotoxin Res. 2020, 36, 83-91. [CrossRef] [PubMed]

47. Castlebury, L.A.; Rossman, A.Y.; Sung, G.-H.; Hyten, A.S.; Spatafora, J.W. Multigene Phylogeny Reveals New Lineage for Stachybotrys chartarum, the Indoor Air Fungus. Mycol. Res. 2004, 108, 864-872. [CrossRef] [PubMed]

48. Summerbell, R.C.; Gueidan, C.; Schroers, H.-J.; de Hoog, G.S.; Starink, M.; Rosete, Y.A.; Guarro, J.; Scott, J.A. Acremonium Phylogenetic Overview and Revision of Gliomastix, Sarocladium, and Trichothecium. Stud. Mycol. 2011, 68, 139-162. [CrossRef]

49. Rossman, A.Y.; McKemy, J.M.; Pardo-Schultheiss, R.A.; Schroers, H.-J. Molecular Studies of the Bionectriaceae Using Large Subunit RDNA Sequences. Mycologia 2001, 93, 100-110. [CrossRef]

50. Xu, J.; Takasaki, A.; Kobayashi, H.; Oda, T.; Yamada, J.; Mangindaan, R.E.P.; Ukai, K.; Nagai, H.; Namikoshi, M. Four New Macrocyclic Trichothecenes from Two Strains of Marine-Derived Fungi of the Genus Myrothecium. J. Antibiot. 2006, 59, 451-455. [CrossRef]

51. Abbas, H.K.; Johnson, B.B.; Shier, W.T.; Tak, H.; Jarvis, B.B.; Boyette, C.D. Phytotoxicity and Mammalian Cytotoxicity of Macrocyclic Trichothecene Mycotoxins from Myrothecium verrucaria. Phytochemistry 2002, 59, 309-313. [CrossRef]

52. Sun, T.-T.; Zhu, H.-J.; Cao, F. Chapter 6-The Fungal Myrothecium Genus as a Source of Bioactive Secondary Metabolites. Stud. Nat. Prod. Chem. 2020, 65, 195-237. [CrossRef]

53. Frazer, S.; Magan, N.; Aldred, D. The Influence of Water Activity and Temperature on Germination, Growth and Sporulation of Stachybotrys chartarum Strains. Mycopathologia 2011, 172, 17-23. [CrossRef]

54. Walsh, T.J.; Hayden, R.T.; Larone, D.H. Larone's Medically Important Fungi, 6th ed.; American Society of Microbiology: Washington, DC, USA, 2018. [CrossRef]

55. De Silva, L.B.; Herath, W.H.M.W.; Gunawardena, D.S.S.; Wijesundera, R.L.C.; Medis, S.A.; Choudhary, M.I.; Clardy, J. Bisbynin, a Novel Secondary Metabolite from the Fungus Stachybotrys bisbyi (Srinivasan) Barron. Tetrahedron Lett. 1995, 36, 1997-2000. [CrossRef]

56. Samson, J.R.A.; Houbraken, U.; Thrane, J.C.; Frisvad, B.A. Food and Indoor Fungi; CBS Laboratory Manual Series; CBS-KNAW Fungal Biodiversity Centre: Utrecht, The Netherlands, 2010.

57. Fassatiová, O. Plísně a Vláknité Houby v Technické Mikrobiologii (Original Title)/Grzyby Mikroskopowe w Mikrobiologii Technicznej (Translation into Polish); Translation, O.H., Ed.; Státní Nakladatelství Tech-Nické Literatury/Wydawnictwa Naukowo-Techniczne: Prague, Czech Republic, 1979.

58. Ochiai, E.; Kamei, K.; Hiroshima, K.; Watanabe, A.; Hashimoto, Y.; Sato, A.; Ando, A. The Pathogenicity of Stachybotrys chartarum. Nihon Ishinkin Gakkai Zasshi 2005, 46, 109-117. [CrossRef]

59. Karunasena, E.; Cooley, J.D.; Douglas, D.R.; Straus, D.C. Protein Translation Inhibition by Stachybotrys chartarum Conidia with and without the Mycotoxin Containing Polysaccharide Matrix. Mycopathologia 2004, 158, 87-97. [CrossRef] [PubMed]

60. Jarvis, B.B. Stachybotrys chartarum: A Fungus for Our Time. Phytochemistry 2003, 64, 53-60. [CrossRef]

61. Jarvis, B.B.; Sorenson, W.G.; Hintikka, E.-L.; Nikulin, M.; Zhou, Y.; Jiang, J.; Wang, S.; Hinkley, S.; Etzel, R.A.; Dearborn, D. Study of toxin production by isolates of Stachybotrys chartarum and Memnoniella echinata isolated during a study of pulmonary hemosiderosis in infants. Appl. Environ. Microbiol. 1998, 64, 3620-3625. [CrossRef] [PubMed]

62. Tucker, K.; Stolze, J.L.; Kennedy, A.H.; Money, N.P. Biomechanics of Conidial Dispersal in the Toxic Mold Stachybotrys chartarum. Fungal Genet. Biol. 2007, 44, 641-647. [CrossRef] [PubMed]

63. Hyde, K.D.; Goh, T.K.; Taylor, J.E.; FrÖHlich, J. Byssosphaeria, Chaetosphaeria, Niesslia and Ornatispora Gen. Nov., from Palms. Mycol. Res. 1999, 103, 1423-1439. [CrossRef]

64. Whitton, S.R.; McKenzie, E.H.C.H.K. Teleomorphic Microfungi Associated with Pandanaceae. In Fungi Associated with Pandanaceae; Springer: Dordecht, The Netherlands; Chiang Rai, Thailand, 2012; pp. 23-124. [CrossRef]

65. Li, S.; Hartman, G.L.; Jarvis, B.; Tak, H. A Stachybotrys chartarum Isolate from Soybean. Mycopathologia 2002, 154, 41-49. [CrossRef]

66. Wylke, T.D.; Morehouse, L.G. (Eds.) Mycotoxic Fungi, Mycotoxins, Mycotoxicoses. In Mycotoxic Fungi, Mycotoxins, Mycotoxicoses: An Encyclopedic Handbook. Volume 1: Mycotoxic Fungi and Chemistry of Mycotoxins; Marcel Dekker Inc.: New York, NY, USA, 1977.

67. Fog Nielsen, K. Mycotoxin Production by Indoor Molds. Fungal Genet. Biol. 2003, 39, 103-117. [CrossRef] 
68. Buerman, E.C.; Worobo, R.W.; Padilla-Zakour, O.I. Thermal Resistance of Xerophilic Fungi in Low-Water-Activity (0.70 to 0.80) Confectionery Model Foods. J. Food Prot. 2019, 82, 390-394. [CrossRef]

69. Vinnere Pettersson, O.; Leong, S.L. Fungal Xerophiles (Osmophiles); John Wiley \& Sons: Hoboken, NJ, USA, 2011. [CrossRef]

70. Brasel, T.L.; Martin, J.M.; Carriker, C.G.; Wilson, S.C.; Straus, D. Detection of Airborne Stachybotrys chartarum Macrocyclic Trichothecene Mycotoxins in the Indoor Environment. Appl. Environ. Microbiol. 2005, 71, 7376-7388. [CrossRef]

71. Vašutová, M.; Mleczko, P.; López-García, A.; Maček, I.; Boros, G.; Ševčík, J.; Fujii, S.; Hackenberger, D.; Tuf, I.H.; Hornung, E.; et al Taxi Drivers: The Role of Animals in Transporting Mycorrhizal Fungi. Mycorrhiza 2019, 29, 413-434. [CrossRef]

72. Lewis, G.; Harriman, G.; Brundrett, R.K. Humidity Control Design Guide for Commercial and Institutional Buildings; American Society of Heating, Refrigerating and Air-Conditioning Engineers (ASHRAE): Atlanta, GA, USA, 2001.

73. US EPA. Mold Remediation in Schools and Commercial Buildings Guide: Chapter 1. Available online: https://www.epa.gov/ mold/mold-remediation-schools-and-commercial-buildings-guide-chapter-1 (accessed on 9 January 2021)

74. Pournou, A.; Bogomolova, E. Fungal Colonization on Excavated Prehistoric Wood: Implications for In-Situ Display. Int. Biodeterior Biodegrad. 2009, 63, 371-378. [CrossRef]

75. Korpi, A.; Pasanen, A.-L.; Viitanen, H. Volatile Metabolites of Serpula Lacrymans, Coniophora Puteana, Poria Placenta, Stachybotrys chartarum and Chaetomium globosum. Build. Environ. 1998, 34, 205-211. [CrossRef]

76. Nielsen, K.F.; Hansen, M.Ø.; Larsen, T.O.; Thrane, U. Production of Trichothecene Mycotoxins on Water Damaged Gypsum Boards in Danish Buildings. Int. Biodeterior. Biodegrad. 1998, 42, 1-7. [CrossRef]

77. Szostak-Kotowa, J. Biodeterioration of Textiles. Int. Biodeterior. Biodegrad. 2004, 53, 165-170. [CrossRef]

78. Zyska, B. Fungi Isolated from Library Materials: A Review of the Literature. Int. Biodeterior. Biodegrad. 1997, 40, 43-51. [CrossRef]

79. Drobotko, V.G. Stachybotryotoxicosis. A New Disease of Horses and Humans. Am. Rev. Sov. Med. 1945, 2, 238-242.

80. Harrach, B.; Bata, A.; Bajmócy, E.; Benko, M. Isolation of Satratoxins from the Bedding Straw of a Sheep Flock with Fatal Stachybotryotoxicosis. Appl. Environ. Microbiol. 1983, 45, 1419-1422. [CrossRef]

81. Gutarowska, B.; Sulyok, M.; Krska, R. A Study of the Toxicity of Moulds Isolated from Dwellings. Indoor Built Environ. 2010, 19, 668-675. [CrossRef]

82. Wagner, A.; Hoffman, M.; Green, C.; Barth, E.; Davidson, C.; Gibbs, S.; Scarpino, P. Inactivation of Stachybotrys chartarum Grown on Gypsum Board Using Aerosolized Chemical Agents. J. Environ. Eng. Sci. 2011, 5, 75-79. [CrossRef]

83. Fantucci, S.; Isaia, F.; Serra, V.; Dutto, M. Insulating Coat to Prevent Mold Growth in Thermal Bridges. Energy Procedia 2017, 134, 414-422. [CrossRef]

84. Pasanen, A.-L.; Nikulin, M.; Berg, S.; Hintikka, E.-L. Stachybotrys atra Corda May Produce Mycotoxins in Respirator Filters in Humid Environments. Am. Ind. Hyg. Assoc. J. 1994, 55, 62-65. [CrossRef]

85. Haugland, R.A.; Heckman, J.L. Identification of Putative Sequence Specific PCR Primers for Detection of the Toxigenic Fungal Species Stachybotrys chartarum. Mol. Cell. Probes 1998, 12, 387-396. [CrossRef] [PubMed]

86. Kendrick, B. The Fifth Kingdom; Focus Pub.: Newburyport, MA, Canada, 2000.

87. Jarvis, B.B. Macrocyclic Trichothecenes. In Mycotoxins and Phytoalexins; Sharma, R.P., Salunkhe, D.K.E., Eds.; CRC Press: Boca Raton, FL, USA, 1991; pp. 361-421.

88. Rashmir-Raven, A.M. Chapter 18 -Disorders of the Skin, 4th ed.; Reed, S.M., Bayly, W.M., Sellon, D.C.B.T.-E.I.M., Saunders, W.B., Eds.; Elsevier: Amsterdam, The Netherlands, 2018; pp. 1159-1216. [CrossRef]

89. Nelson, B.D. Stachybotrys chartarum: The Toxic Indoor Mold. Available online: http://www.apsnet.org/online/feature/ stachybotrys/ (accessed on 13 January 2021). [CrossRef]

90. Hintikka, E.L. Stachybotryotoxicosis as a Veterinary Problem. In Mycotoxins in Human and Animal Health; Rodricks, J.V., Hesseltine, C.W., Mehlman, M.A.E., Eds.; Pathotox Publishers Park Forest South, Ill.: Chicago, IL, USA, 1977; pp. 277-284.

91. Tantaoui-Elaraki, A.; Mekouar, S.L.; el Hamidi, M.; Senhaji, M. Toxigenic Strains of Stachybotrys atra Associated with Poisonous Straw in Morocco. Vet. Hum. Toxicol. 1994, 36, 93-96. [PubMed]

92. Mostrom, M.S.; Raisbeck, M.F. Trichothecenes. In Veterinary Toxicology; Elsevier: Amsterdam, The Netherlands, 2007; pp. 951-976.

93. Wyllie, T.D.; Morehouse, L.G. Mycotoxicoses of Domestic and Laboratory Animals, Poultry, and Aquatic Invertebrates and Vertebrates; M. Dekker: New York, NY, USA, 1978.

94. Paterson, R.R.M.; Lima, N. Toxicology of Mycotoxins. EXS 2010, 100, 31-63. [CrossRef] [PubMed]

95. Haschek, W.M.; Rousseaux, C.G.; Wallig, M.A.; Bolon, B.; Ochoa, R. Haschek and Rousseaux's Handbook of Toxicologic Pathology; Elsevier Science: Amsterdam, The Netherlands, 2013.

96. Miller, J.D.; Rand, T.G.; Jarvis, B.B. Stachybotrys chartarum: Cause of Human Disease or Media Darling? Med. Mycol. 2003, 41, 271-291. [CrossRef]

97. Sudakin, D.L. Stachybotrys chartarum: Current Knowledge of Its Role in Disease. MedGenMed 2000, 2, E11.

98. Johanning, E.; Landsbergis, P.; Gareis, M.; Yang, C.S.; Olmsted, E. Clinical Experience and Results of a Sentinel Health Investigation Related to Indoor Fungal Exposure. Environ. Health Perspect. 1999, 107 (Suppl. 3), 489-494. [CrossRef]

99. Cassimos, C.D.; Chryssanthopoulos, C.; Panagiotidou, C. Epidemiologic Observations in Idiopathic Pulmonary Hemosiderosis. J. Pediatr. 1983, 102, 698-702. [CrossRef]

100. Elidemir, O.; Colasurdo, G.N.; Rossmann, S.N.; Fan, L.L. Isolation of Stachybotrys from the Lung of a Child with Pulmonary Hemosiderosis. Pediatrics 1999, 104, 964-966. [CrossRef] 
101. Etzel, R.A.; Montaña, E.; Sorenson, W.G.; Kullman, G.J.; Allan, T.M.; Dearborn, D.G.; Olson, D.R.; Jarvis, B.B.; Miller, J.D. Acute Pulmonary Hemorrhage in Infants Associated with Exposure to Stachybotrys atra and Other Fungi. Arch. Pediatr. Adolesc. Med. 1998, 152, 757-762. [CrossRef]

102. Kuhn, D.M.; Ghannoum, M.A. Indoor Mold, Toxigenic Fungi, and Stachybotrys chartarum: Infectious Disease Perspective. Clin. Microbiol. Rev. 2003, 16, 144-172. [CrossRef]

103. Acute Pulmonary Hemorrhage/Hemosiderosis among Infants-Cleveland, January 1993-November 1994. MMWR Morb. Mortal. Wkly. Rep. 1994, 43, 881-883.

104. Sorenson, W.G.; Frazer, D.G.; Jarvis, B.B.; Simpson, J.; Robinson, V.A. Trichothecene Mycotoxins in Aerosolized Conidia of Stachybotrys atra. Appl. Environ. Microbiol. 1987, 53, 1370-1375. [CrossRef] [PubMed]

105. Jarvis, B.B. Chemistry and Toxicology of Molds Isolated from Water-Damaged Buildings BT_Mycotoxins and Food Safety; DeVries, J.W., Trucksess, M.W., Jackson, L.S., Eds.; Springer US: Boston, MA, USA, 2002; pp. 43-52. [CrossRef]

106. Gareis, M.; Gottschalk, C. Stachybotrys spp. and the Guttation Phenomenon. Mycotoxin Res. 2014, 30, 151-159. [CrossRef] [PubMed]

107. Gregory, L.; Pestka, J.J.; Dearborn, D.G.; Rand, T.G. Localization of Satratoxin-G in Stachybotrys chartarum Spores and SporeImpacted Mouse Lung Using Immunocytochemistry. Toxicol. Pathol. 2004, 32, 26-34. [CrossRef] [PubMed]

108. Koch's Postulates. Available online: https://mpkb.org/home/pathogenesis/kochs_postulates (accessed on 14 February 2022).

109. Croston, T.L.; Lemons, A.R.; Barnes, M.A.; Goldsmith, W.T.; Orandle, M.S.; Nayak, A.P.; Germolec, D.R.; Green, B.J.; Beezhold, D.H. Inhalation of Stachybotrys chartarum Fragments Induces Pulmonary Arterial Remodeling. Am. J. Respir. Cell Mol. Biol. 2019, 62, 563-576. [CrossRef] [PubMed]

110. Lemons, A.R.; Croston, T.L.; Goldsmith, W.T.; Barnes, M.A.; Jaderson, M.A.; Park, J.-H.; McKinney, W.; Beezhold, D.H.; Green, B.J Cultivation and Aerosolization of Stachybotrys chartarum for Modeling Pulmonary Inhalation Exposure. Inhal. Toxicol. 2019, 31, 446-456. [CrossRef] [PubMed]

111. Croft, W.A.; Jarvis, B.B.; Yatawara, C.S. Airborne Outbreak of Trichothecene Toxicosis. Atmos. Environ. 1986, $20,549-552$. [CrossRef]

112. Vesper, S.J.; Vesper, M.J. Stachylysin May Be a Cause of Hemorrhaging in Humans Exposed to Stachybotrys chartarum. Infect. Immun. 2002, 70, 2065-2069. [CrossRef]

113. Jagels, A.; Stephan, F.; Ernst, S.; Lindemann, V.; Cramer, B.; Hübner, F.; Humpf, H.-U. Artificial vs Natural Stachybotrys Infestation-Comparison of Mycotoxin Production on Various Building Materials. Indoor Air 2020, 30, 1268-1282. [CrossRef]

114. Shi, C.; Smith, M.L.; Miller, J.D. Characterization of Human Antigenic Proteins SchS21 and SchS34 from Stachybotrys Chartarum. Int. Arch. Allergy Immunol. 2011, 155, 74-85. [CrossRef] [PubMed]

115. Wilkins, K.; Nielsen, K.F.; Din, S.U. Patterns of Volatile Metabolites and Nonvolatile Trichothecenes Produced by Isolates of Stachybotrys, Fusarium, Trichoderma, Trichothecium and Memnoniella. Environ. Sci. Pollut. Res. 2003, 10, 162. [CrossRef]

116. Rudert, A.; Portnoy, J. Mold Allergy: Is It Real and What Do We Do about It? Expert Rev. Clin. Immunol. 2017, 13, 823-835. [CrossRef]

117. Pestka, J.J.; Yike, I.; Dearborn, D.G.; Ward, M.D.W.; Harkema, J.R. Stachybotrys chartarum, Trichothecene Mycotoxins, and Damp Building-Related Illness: New Insights into a Public Health Enigma. Toxicol. Sci. 2008, 104, 4-26. [CrossRef] [PubMed]

118. Kordula, T.; Banbula, A.; Macomson, J.; Travis, J. Isolation and Properties of Stachyrase A, a Chymotrypsin-like Serine Proteinase from Stachybotrys chartarum. Infect. Immun. 2002, 70, 419-421. [CrossRef] [PubMed]

119. Weiss, A.; Chidekel, A.S. Acute Pulmonary Hemorrhage in a Delaware Infant after Exposure to Stachybotrys atra. Del. Med. J. 2002, 74, 363-368.

120. Dearborn, D.G.; Smith, P.G.; Dahms, B.B.; Allan, T.M.; Sorenson, W.G.; Montana, E.; Etzel, R.A. Clinical Profile of 30 Infants with Acute Pulmonary Hemorrhage in Cleveland. Pediatrics 2002, 110, 627-637. [CrossRef]

121. Gnat, S.; Łagowski, D.; Nowakiewicz, A.; Dylag, M. A Global View on Fungal Infections in Humans and Animals: Infections Caused by Dimorphic Fungi and Dermatophytoses. J. Appl. Microbiol. 2021, 131, 2688-2704. [CrossRef]

122. Ayoubi, N.; Dass, V.L. Black Mold: A Case Presentation and Discussion of Cutaneous Stachybotrys chartarum Infection. Dermatol. Arch. 2019, 3, 80-81. [CrossRef]

123. Laniado-Laborín, R.; Cabrales-Vargas, M.N. Amphotericin B: Side Effects and Toxicity. Rev. Iberoam. Micol. 2009, 26, $223-227$. [CrossRef]

124. Semis, M.; Dadwal, S.S.; Tegtmeier, B.R.; Wilczynski, S.P.; Ito, J.I.; Kalkum, M. First Case of Invasive Stachybotrys Sinusitis. Clin. Infect. Dis. 2021, 72, 1386-1391. [CrossRef] [PubMed]

125. Seroy, J.; Antiporta, P.; Grim, S.A.; Proia, L.A.; Singh, K.; Clark, N.M. Aspergillus calidoustus Case Series and Review of the Literature. Transpl. Infect. Dis. 2017, 19, e12755. [CrossRef] [PubMed]

126. Glampedakis, E.; Cassaing, S.; Fekkar, A.; Dannaoui, E.; Bougnoux, M.-E.; Bretagne, S.; Neofytos, D.; Schreiber, P.W.; Hennequin, C.; Morio, F.; et al. Invasive Aspergillosis Due to Aspergillus Section Usti: A Multicenter Retrospective Study. Clin. Infect. Dis. 2021, 72, 1379-1385. [CrossRef] [PubMed]

127. Egli, A.; Fuller, J.; Humar, A.; Lien, D.; Weinkauf, J.; Nador, R.; Kapasi, A.; Kumar, D. Emergence of Aspergillus calidoustus Infection in the Era of Posttransplantation Azole Prophylaxis. Transplantation 2012, 94, 403-410. [CrossRef]

128. Yike, I.; Vesper, S.; Tomashefski, J.F.; Dearborn, D.G. Germination, Viability and Clearance of Stachybotrys chartarum in the Lungs of Infant Rats. Mycopathologia 2003, 156, 67-75. [CrossRef] [PubMed] 
129. Blevins, S.M.; Bronze, M.S. Robert Koch and the 'Golden Age' of Bacteriology. Int. J. Infect. Dis. 2010, 14, e744-e751. [CrossRef]

130. Page, E.H.; Trout, D.B. The Role of Stachybotrys Mycotoxins in Building-Related Illness. AIHAJ Am. Ind. Hyg. Assoc. 2001, 62, 644-648. [CrossRef]

131. Chung, Y.-J.; Yang, G.-H.; Islam, Z.; Pestka, J.J. Up-Regulation of Macrophage Inflammatory Protein-2 and Complement 3A Receptor by the Trichothecenes Deoxynivalenol and Satratoxin G. Toxicology 2003, 186, 51-65. [CrossRef]

132. Latgé, J.P. Aspergillus fumigatus and Aspergillosis. Clin. Microbiol. Rev. 1999, 12, 310-350. [CrossRef]

133. Ulrich, S.; Schäfer, C. Toxin Production by Stachybotrys chartarum Genotype S on Different Culture Media. J. Fungi 2020, 6, 159. [CrossRef]

134. Aleksic, B.; Bailly, S.; Draghi, M.; Pestka, J.J.; Oswald, I.P.; Robine, E.; Bailly, J.D.; Lacroix, M.Z. Production of Four Macrocyclic Trichothecenes by Stachybotrys chartarum during Its Development on Different Building Materials as Measured by UPLC-MS/MS. Build. Environ. 2016, 106, 265-273. [CrossRef]

135. Hinkley, S.F.; Mazzola, E.P.; Fettinger, J.C.; Lam, Y.-F.; Jarvis, B.B. Atranones A-G, from the Toxigenic Mold Stachybotrys chartarum. Phytochemistry 2000, 55, 663-673. [CrossRef]

136. Vesper, S.J.; Magnuson, M.L.; Dearborn, D.G.; Yike, I.; Haugland, R.A. Initial Characterization of the Hemolysin Stachylysin from Stachybotrys chartarum. Infect. Immun. 2001, 69, 912-916. [CrossRef] [PubMed]

137. Nayak, A.P.; Green, B.J.; Beezhold, D.H. Fungal hemolysins. Med. Mycol. 2013, 51, 1-16. [CrossRef]

138. Rakkestad, K.E.; Skaar, I.; Ansteinsson, V.E.; Solhaug, A.; Holme, J.A.; Pestka, J.J.; Samuelsen, J.T.; Dahlman, H.J.; Hongslo, J.K.; Becher, R. DNA Damage and DNA Damage Responses in THP-1 Monocytes after Exposure to Spores of Either Stachybotrys chartarum or Aspergillus versicolor or to T-2 Toxin. Toxicol. Sci. 2010, 115, 140-155. [CrossRef]

139. de Hoog, G.S. Risk Assessment of Fungi Reported from Humans and Animals*. Mycoses 1996, 39, 407-417. [CrossRef]

140. Zyska, B. Fungi in Indoor Air in European Countries. Mikol. Lek. 2001, 8, 127-140.

141. Mahmoudi, M.; Gershwin, M. Sick Building Syndrome. III. Stachybotrys chartarum. J. Asthma 2000, 37, 191-198. [CrossRef]

142. Reynolds, K.A.; Boone, S.; Bright, K.R.; Gerba, C.P. Occurrence of Household Mold and Efficacy of Sodium Hypochlorite Disinfectant. J. Occup. Environ. Hyg. 2012, 9, 663-669. [CrossRef]

143. Martyny, J.W.; Harbeck, R.J.; Pacheco, K.; Barker, E.A.; Sills, M.; Silveira, L.; Arbuckle, S.; Newman, L. Aerosolized Sodium Hypochlorite Inhibits Viability and Allergenicity of Mold on Building Materials. J. Allergy Clin. Immunol. 2005, 116, 630-635. [CrossRef]

144. Chakravarty, P.; Kovar, B. Engineering Case Report. J. Occup. Environ. Hyg. 2013, 10, D11-D16. [CrossRef] [PubMed]

145. Ogar, A.; Tylko, G.; Turnau, K. Antifungal Properties of Silver Nanoparticles against Indoor Mould Growth. Sci. Total Environ. 2015, 521-522, 305-314. [CrossRef] [PubMed]

146. Pereira, W.E.; Hoyano, Y.; Summons, R.E.; Bacon, V.A.; Duffield, A.M. Chlorination Studies II. The Reaction of Aqueous Hypochlorous Acid with $\alpha$-Amino Acids and Dipeptides. Biochim. Biophys. Acta Gen. Subj. 1973, 313, 170-180. [CrossRef]

147. Rossoni, E.M.M.; Gaylarde, C.C. Comparison of Sodium Hypochlorite and Peracetic Acid as Sanitising Agents for Stainless Steel Food Processing Surfaces Using Epifluorescence Microscopy. Int. J. Food Microbiol. 2000, 61, 81-85. [CrossRef]

148. Srinivasan, S.; Velusamy, G.; Munshi, M.A.I.; Radhakrishnan, K.; Tiwari, R.V.C. Comparative Study of Antifungal Efficacy of Various Endodontic Irrigants with and without Clotrimazole in Extracted Teeth Inoculated with Candida Albicans. J. Contemp. Dent. Pract. 2020, 21, 1325-1330. [CrossRef] [PubMed]

149. Chen, P.; Eggleston, P.A. Allergenic Proteins Are Fragmented in Low Concentrations of Sodium Hypochlorite. Clin. Exp. Allergy 2001, 31, 1086-1093. [CrossRef] [PubMed]

150. Barnes, C.S.; Kennedy, K.; Johnson, L.; Forrest, E.; Gard, L.; Pacheco, F.; Amado, M.; Portnoy, J. Use of Dilute Sodium Hypochlorite Spray and Home Cleaning to Reduce Indoor Allergen Levels and Improve Asthma Health Parameters. Ann. Allergy Asthma Immunol. Off. Publ. Am. Coll. Allergy Asthma Immunol. 2008, 101, 551-552. [CrossRef]

151. Fu, E.; McCue, K.; Boesenberg, D.F. 1-Chemical Disinfection of Hard Surfaces-Household, Industrial and Institutional Settings; Elsevier Science B.V.: Amsterdam, The Netherlands, 2007; pp. 573-592. [CrossRef]

152. Arthur, R. Damp Indoor Spaces and Health; The National Academies Press: Washington, DC, USA, 2004. [CrossRef]

153. Menetrez, M.Y.; Foarde, K.K.; Webber, T.D.; Dean, T.R.; Betancourt, D.A. Testing Antimicrobial Paint Efficacy on Gypsum Wallboard Contaminated with Stachybotrys chartarum. J. Occup. Environ. Hyg. 2007, 5, 63-66. [CrossRef]

154. Whiley, H.; Gaskin, S.; Schroder, T.; Ross, K. Antifungal Properties of Essential Oils for Improvement of Indoor Air Quality: A Review. Rev. Environ. Health 2018, 33, 63-76. [CrossRef]

155. Bassolé, I.H.N.; Juliani, H.R. Essential Oils in Combination and Their Antimicrobial Properties. Molecules 2012, 17, $3989-4006$. [CrossRef]

156. Šegvić Klarić, M.; Kosalec, I.; Mastelić, J.; Piecková, E.; Pepeljnak, S. Antifungal Activity of Thyme (Thymus vulgaris L.) Essential Oil and Thymol against Moulds from Damp Dwellings. Lett. Appl. Microbiol. 2007, 44, 36-42. [CrossRef] [PubMed]

157. Biermaier, B.; Gottschalk, C.; Schwaiger, K.; Gareis, M. Occurrence of Stachybotrys chartarum Chemotype S in Dried Culinary Herbs. Mycotoxin Res. 2015, 31, 23-32. [CrossRef] [PubMed]

158. Peèiulytë, D. Effect of Tea Tree Essential Oil on Microorganisms 2. Evaluation of Fungal Reaction to Tea Tree Oil under Different Conditions. Biologija 2005, 2, 21-28. 